\title{
Plastic Formed and Spot Welded Joints Strength of S350GD+Z Steel
}

\author{
L'uboš KAŠČÁK, Jacek MUCHA, Waldemar WITKOWSKI
}

\begin{abstract}
This paper presents a research of the lap joint shear strength of $S 350 G D+Z$ sheet material joined by resistance spot welding. The resistance spot welding process was done for five values of welding current. The joints strength structure analysis was done for the shearing curves. The influence of the welding current on the joints maximum strength and the shear curve of the resistance spot welded joints was presented. Welding current increase influence efficiency on the joints strength was analyzed. The analysis of the cold plastic formed joining technologies (clinching) was also presented. The clinching joints were made by using different tool types and uniform values of embossment minimum thickness. The influence of tool shape on the joint strength was described. In the case of round clinching joints the influence of forming force increase on the joints strength was studied.
\end{abstract}

Keywords: clinching; joints strength; load-elongation curves; resistant welding

\section{INTRODUCTION}

The S350GD+Z material sheets (mat. number 1.0529) [1] are popular in thin-walled structure industrial branch. Cold-formed profiles for lightweight steel framing constructions, housings, supporting structures among other things are made of it. The $\mathrm{S} 350 \mathrm{GD}+\mathrm{Z}$ steel is used in structural applications especially if the required minimal yield strength is equal or greater than $350 \mathrm{MPa}$. This steel is used when the sheets are subjected to intensive plastic deforming, which leads to the spatial forms formation. The most common way to join the elements made of this steel is riveting (blind rivet - BR) or joining by using screws (self-drilling screw - SC). Specific requirements for thinwalled components joining, e.g. in building industry, are regulated and presented in the EUROCODE standard [2, 3 ]. One of the other joining methods is forming by pressing - rosettes joint $[4,5]$. Joining of $S 350 \mathrm{GD}+Z$ steel sheets provides quite high load capacity, but it requires adequate access for tools and space in the profile. These two joining methods require to make a hole and to position elements before merging. Self-drilling screw joints have higher load capacity than blind rivet joints [6]. Screws are not cut under a shearing load, but they are pulled out "thread by thread" from the sheet. For blind rivet joints a common separation mechanism is river failure. Clinching (CL) is a cold joining method, and resistance spot welding causes changes in the joined materials sheet $[7,8]$. Thermal changes of material structures affect the joint strength [9].

In the case of less important sheet structures square clinching (RCL) joints are often used (Fig. 1). In case of high joint strength requirement blind rivet joints and spot welded joints are applied.

Traditional construction materials are increasingly being replaced by materials with high yield strength. Hence, it is possible to reduce sheet thickness while maintaining adequate strength. Thanks to their increased strength, high yield strength and resistance to corrosion, coated structural steel products are rapidly gaining significance for applications in the automotive industry and supplement the product range of coated, higher-strength multiphase steel grades.

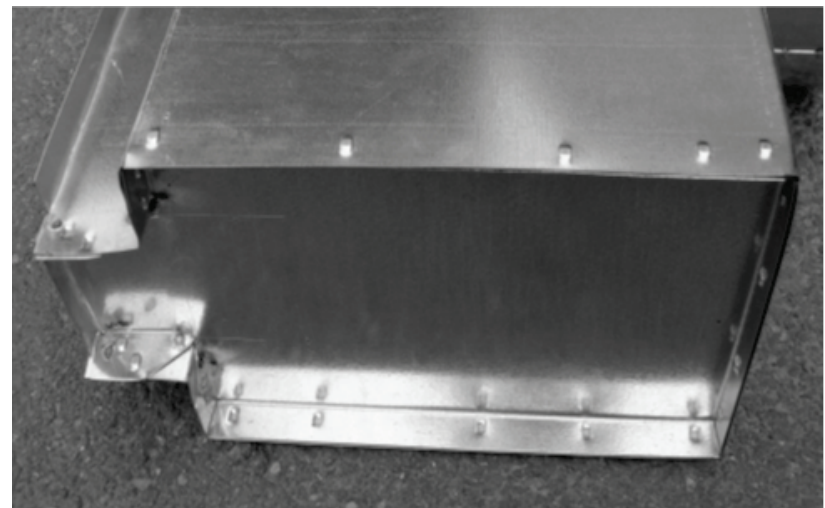

Figure 1 Example of pressed joint use in thin-walled structure of the industrial air conditioning duct

Nowadays, intensive research related development of the pressed joint technology use is carried out. Recent modifications of clinching joining technology were described in several papers $[10 \div 15]$. The development of sheet metal joining by redrawing is a two-step pressing process. The modified joining process for an aluminum alloy sheet was presented by Chen [16]. Still main types of clinching forming processes are used, due to simple design of the tools. Extremely useful tools used in designing process of clinching joints are computer programs for joint forming simulation. The use of FEM allows analyzing the intensity of sheet deformation $[17 \div 19]$. Despite the clinching technology disadvantages, it can be used for joining non-metallic materials such as plastics and composite materials $[20 \div 22]$. The great potential of clinching joints causes that new implementations of this joining technology are still developed [23].

This paper presents the analysis of the S350GD $+Z$ sheet joining by the resistance spot welding process and by cold pressing joining technology. The joint load capacity was compared to that of a blind rivet joint.

\section{EXPERIMENTAL PROCEDURE}

The influence of welding current value changes on the joint strength of S350GD $+Z$ sheet material was obtained in an experimental research. Lap joints were tested. Joints formed by redrawing sheet material (clinching) were also made, and they were tested in a shearing test. Clinching joints were made with the use of a different forming 
method. In addition, the influence of the forming force on the shearing force for round clinching joint was obtained (control parameter: $X-$ minimum thickness of the embossment).

For the use of comparison of the obtained results of the joint load capacity the blind rivet joint samples were also tested. Rivet had a similar diameter to the RW and CL joints. The experimental tests were performed in the Laboratory of the Machine Design Department at Rzeszow University of Technology and at the Faculty of Mechanical Engineering at the Technical University of Košice.

\subsection{Material Properties}

The joining tests were performed for steel sheets made of S350GD+Z275 (acc. to EN 10326 mat. number 1.0529) of the thickness of $1 \pm 0,05 \mathrm{~mm}$, hot galvanized with coating of $275 \mathrm{~g} / \mathrm{m}^{2}$ of $\sim 20 \mu \mathrm{m}$ thickness. The chemical composition was presented in Tab. 1, and the basic mechanical properties in Tab. 2.

Table 1 Chemical composition of S350GD steel

\begin{tabular}{|c|c|c|c|c|}
\hline $\mathrm{C} / \%$ & $\mathrm{Si} / \%$ & $\mathrm{Mn} / \%$ & $\mathrm{P} / \%$ & $\mathrm{~S} / \%$ \\
\hline 0,036 & 0,030 & 0,241 & 0,241 & $<0,002$ \\
\hline $\mathrm{Cu} / \%$ & $\mathrm{Al} / \%$ & $\mathrm{Cr} / \%$ & $\mathrm{Mo} / \%$ & $\mathrm{Ni} / \%$ \\
\hline 0,028 & 0,082 & 0,020 & 0,023 & 0,011 \\
\hline $\mathrm{V} / \%$ & $\mathrm{Ti} / \%$ & $\mathrm{Nb} / \%$ & $\mathrm{Co} / \%$ & $\mathrm{Fe} / \%$ \\
\hline 0,015 & $<0,002$ & 0,027 & 0,052 & $\mathrm{reszta}$ \\
\hline
\end{tabular}

Table 2 Mechanical properties of S350GD steel

\begin{tabular}{|c|c|c|c|c|}
\hline$R_{\mathrm{p} 0,2} / \mathrm{MPa}$ & $R_{\mathrm{m}} / \mathrm{MPa}$ & $A_{80} / \%$ & $v$ & $E / \mathrm{GPa}$ \\
\hline 350 & 420 & 16 & 0,3 & 2,09 \\
\hline
\end{tabular}

\subsection{Joints Preparation and Tensile Shear Test}

Resistance spot welding was carried out in laboratory conditions by a pneumatic spot welding machine BPK 20 made by VTS ELEKTRO Bratislava. Diameter of working area of the electrode was $d=5 \sqrt{t_{\text {sheet }}}(5 \mathrm{~mm}) . \mathrm{CuCr}$ welding electrodes were used according to the $\mathrm{ON} 42$ 3039.71 standard. The parameters of resistance spot welding $\left(F_{\mathrm{p}}\right.$ - pressing force of electrodes, $T$ - welding time and $I-$ welding current) with marked tested samples are shown in Tab. 3 .

Depending on the blind rivet type, different joint strength is obtained [24]. In the research only most commonly used rivet types for ventilation duct construction joining, were used. Steel blind rivets had the outer diameter of $5 \mathrm{~mm}$. The average force needed to join samples was $3,5 \mathrm{kN}$.

Table 3 Parameters of resistance spot welding process (SW)

\begin{tabular}{|c|c|c|c|c|c|}
\hline \multirow{2}{*}{ Parameters } & \multicolumn{5}{|c|}{ Welding current $I / \mathrm{kA}$} \\
\cline { 2 - 6 } & 5 & 5,5 & 6 & 6,5 & 7 \\
\hline Welding time $T /$ period & 14 & 14 & 14 & 14 & 14 \\
\hline Pressing force $F_{\mathrm{p}} / \mathrm{kN}$ & 3 & 3 & 3 & 3 & 3 \\
\hline
\end{tabular}

Resistance spot welded joints and blind rivet joints were presented in Fig. 2. Clinching joints were made by using three different forming systems (Fig. 3). Forming tools (Fig. 4a) were chosen to provide similar size of hole embossment to weld nuggets $(\sim 5 \mathrm{~mm})$. The steel rivet used in the CR technology had an average hardness of $357 \mathrm{HV}_{01}$, and its main dimensions are shown in Fig. 4b.

The width of joined samples was $40 \mathrm{~mm}$, length $40 \mathrm{~mm}$ and the length between clamps was $120 \mathrm{~mm}$ (Fig. 5). For tensile strength tests five samples were used for each type of joint. The basic geometry of tools used in the pressing technology was presented in Fig. 4. Strength tests were performed until complete separation of the joint by using Instron 3328 testing machine. The traverse speed of 10 $\mathrm{mm} / \mathrm{min}$ of the tensile testing machine ensured constant conditions of the static test.

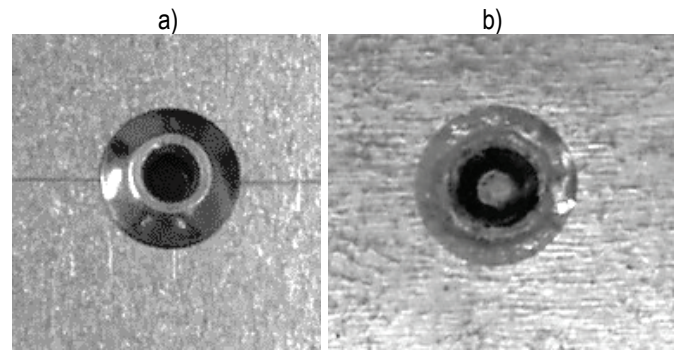

Figure 2 Lap joint: a) blind rivet, b) resistance spot welded

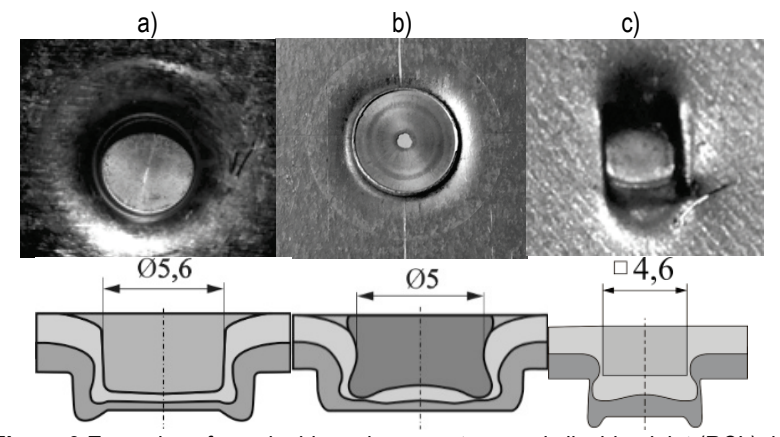

Figure 3 Examples of punch side embossments: round clinching joint (RCL), b) round clinching joint with additional rivet $(\mathrm{CR}), \mathrm{c}$ ) square clinching joint with material incision (SCL).
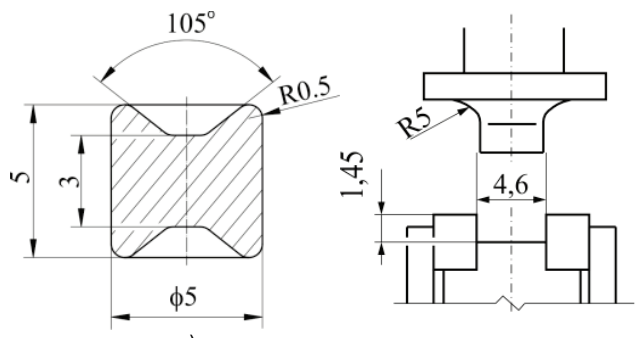

a)
SCL
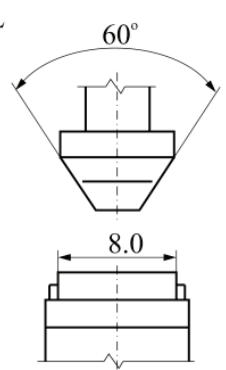

b)
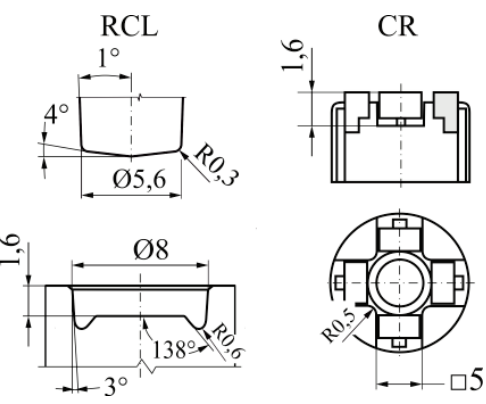

Figure 4 Tools geometry: a) rivet for $\mathrm{CR}$ technology, b) tools for pressed joints (RCL, SCL, CR) 


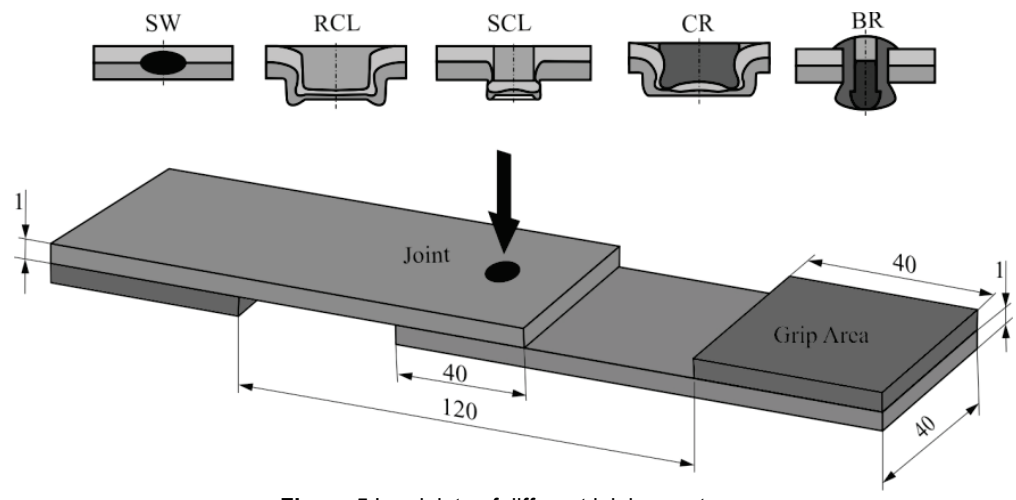

Figure 5 Lap joints of different joining systems

Square clinching joints can be made in 3 versions (Fig. $6)$. For the analysis a RCL variant without sheet cutting was selected (Fig. 6-III)

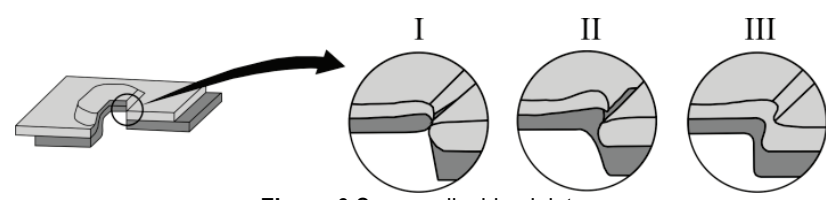

Figure 6 Square clinching joints

\section{RESULTS AND DISCUSSIONS}

Research related to the resistance spot welding process allowed to determine the influence of welding current on the joints strength of S350GD sheets. The welding current value affects creation of an appropriate weld nugget [25]. Sheets used in the experimental research had a zinc coating. Zinc and zinc compound vapours cause significant difficulties for a stable welding process. The main problem is significant porosity of spot welded joints due to trapping of zinc vapours in crystallizing weld metal.

Spot welded joint samples were separated in a tensile shearing test. Sheets did not separate (by cohesion loss) in the weld nugget for all values of the welding current $(I=5$, $5,5,6,6,5,7 \mathrm{kA})$, but around the weld nugget (Fig. 7). Zinc coating, among others, has an influence on that joint destruction mechanism. The influence of the welding current on the sheet material macrostructure, for two values of the welding current, was illustrated in Fig. 8. In the case of $5 \mathrm{kA}$ current the grain changing area and the intermediate area are visible. The area change is constant in a certain section. For $I=7 \mathrm{kA}$ the grain grows significantly in the current flow direction, at the expense of the intermediate area. Changes of the welding current value caused differences in the maximum joints strength and the total dissipated energy (work or area under the load curve) - Fig. 9. Change of the welding current from 5 to $7 \mathrm{kA}$ ( $40 \%$ increase) resulted in separation of the joined samples also in weld nuggets (the maximum joints strength increase of $47 \%$ ).

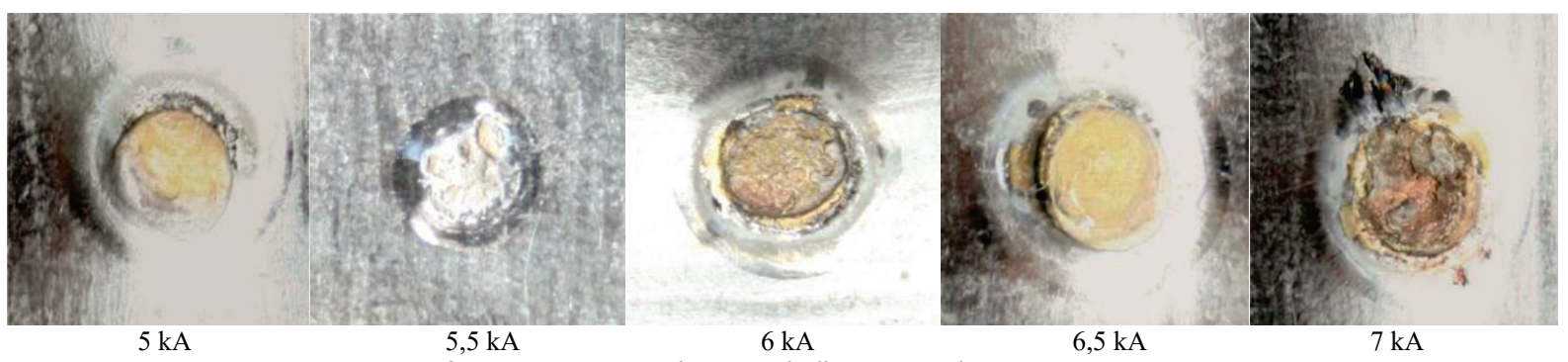

Figure 7 Sheared weld nugget of lap joint of different values for welding current $I$ (kA)
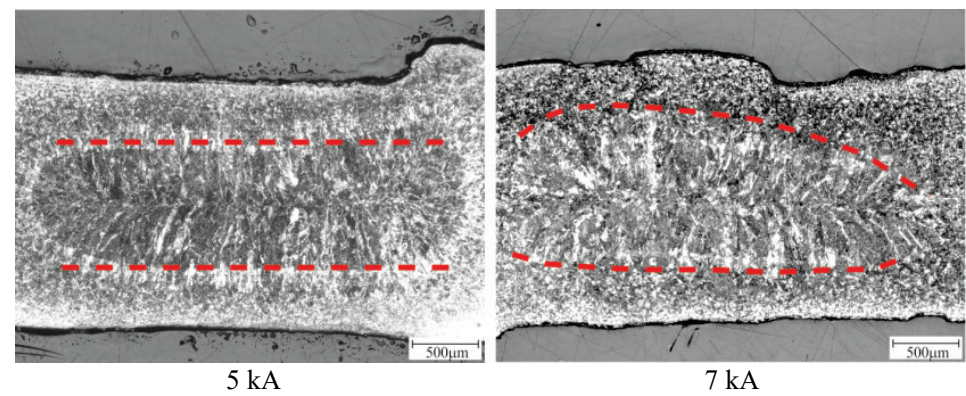

Figure 8 Microstructure of resistance spot welded joints for two different values of welding current $I(\mathrm{kA})$

The increase of joint strength as a function of welding current $(I)$ can be considered as linear (curve 1 in Fig. 10). However, if we specify the dependence between the relative increase of strength and the function of welding current increase, the optimum value can be determined (curve 2 in Fig. 10). The relative increase of shear strength (for the increase of the welding current from 5 to $5,5 \mathrm{kA}$ ) was determined from the equation:

$$
\Delta F_{s \max }^{5,5}=F_{s \max }^{5,5}-F_{s \max }^{5}
$$


where:

$F_{s \max }^{5,5}$ - average value of maximum shearing force of spot welded joint of 5,5 kA welding current,

$F_{s \max }^{5}$ - average value of maximum shearing force of spot welded joint of $5 \mathrm{kA}$ welding current.

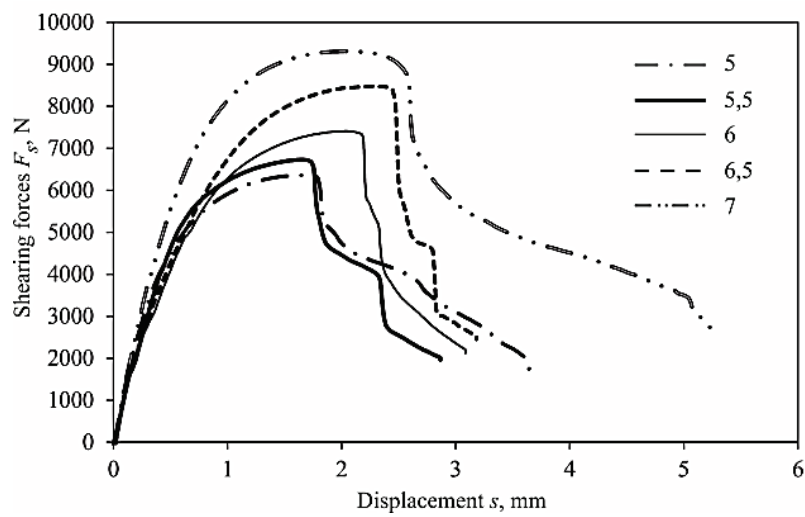

Figure 9 Long-elongation curves of resistance spot welded joint for different values of welding current

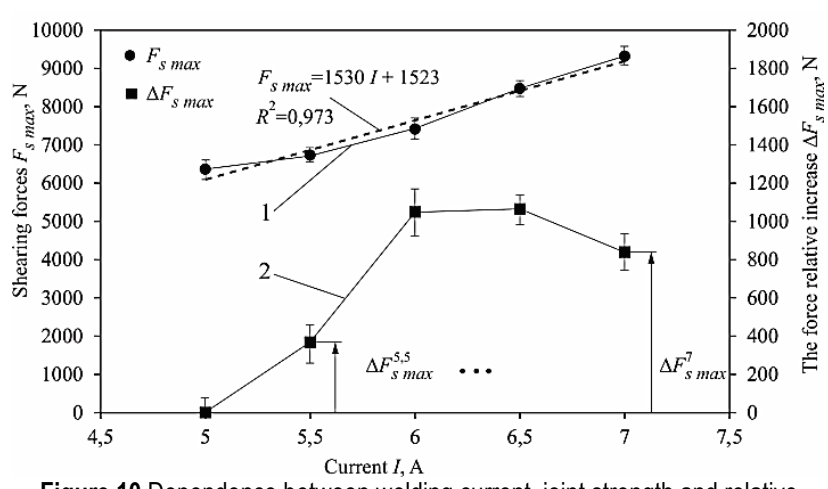

Figure 10 Dependence between welding current, joint strength and relative increase of shearing force value

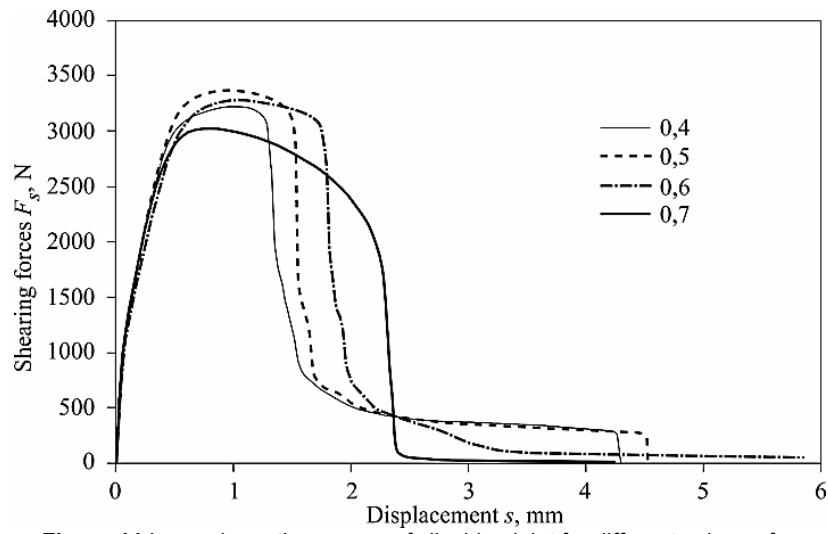

Figure 11 Long-elongation curves of clinching joint for different values of $X$ parameter of $\mathrm{RCL}$ joint

For other values of the welding current $I$ the relative increase of the shearing force was determined.

In the assembly process of thin-walled structures the SW joints are increasingly being replaced by pressed joints like round clinching (RCL) [26, 27]. An analysis of strength of joints, made by using circular uniform tools (punch and die), was done for comparison. As in the case of SW joints for CL joints the process parameters influence the joints load capacity. In Fig. 11 the influence of embossment thickness (and thereby the forming force) on the strength of a RCL lap joint was presented.

During the experimental research, the embossment thickness, for which the interlock is formed, was determined. For the forming force of the parameter $X=0,7$ $\mathrm{mm}$, the increase of forming force for $X=0,6 \mathrm{~mm}$ was compared. Then the forming forces were compared for $X=$ $0,5 \mathrm{~mm}$ and $X=0,6 \mathrm{~mm}$. For the remaining $X$ values, relative changes of the forming force were calculated. Hence, relative increases of the forming force for all values of the $X$ parameter were determined and compared with the average shearing force for the specified $X$ parameter (Fig. 12). For these two parameters the optimum embossment thickness for $X$ is $0,5 \mathrm{~mm}\left(\sim 25 \% \cdot\left(t_{1}+t_{2}\right)\right)$, when taking into account the value of the shearing force and maintaining a relatively low value of the forming force. When selecting the forming force value, also the increase of the forming tools pressure (punch and die) needs to be considered. High tool pressure load and high velocities of sheet material flow increase the tool wear $[28,29]$.

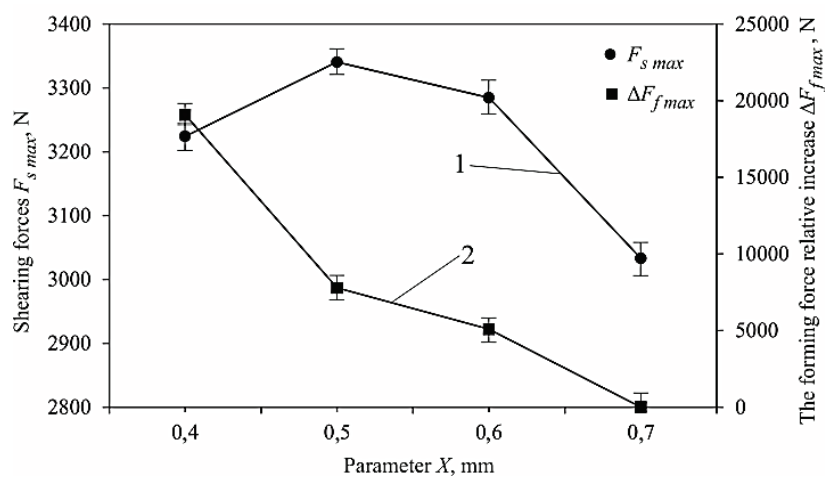

Figure 12 Influence of minimum embossment thickness $(X)$ on the shear strength $\left(F_{s \text { max }}\right)$ of clinching joint
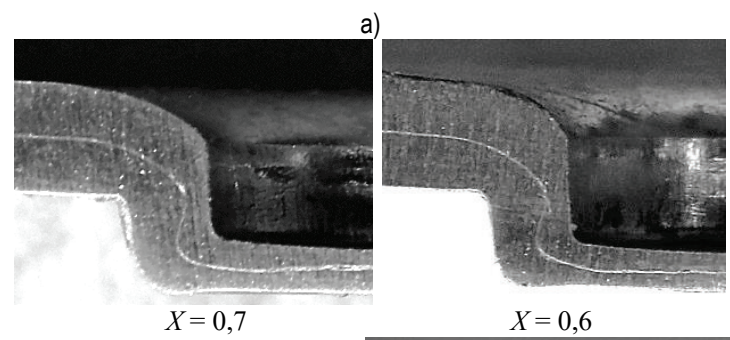

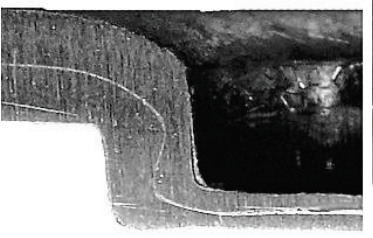

$X=0,5$

b)

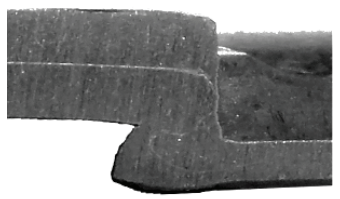

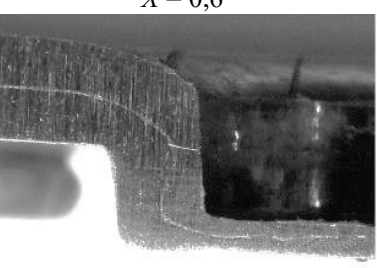

$X=0,4$

c)

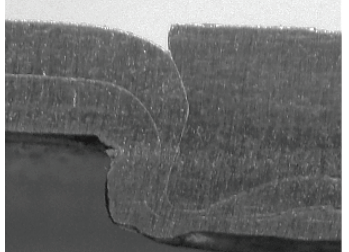

Figure 13 Joints cross-sections: a) RCL, b) SCL $\left(t_{\mathrm{n}}=0,11 \mathrm{~mm}, t_{\mathrm{s}}=1 \mathrm{~m} 14\right.$ $\mathrm{mm}), \mathrm{c}) \operatorname{CR}\left(t_{\mathrm{n}}=0,12 \mathrm{~mm}, t_{\mathrm{s}}=0,27 \mathrm{~mm}\right)$

Depending on the maximum forming force $\left(F_{f \max }\right)$ different embossment thicknesses (parameter $X$ ) were 
obtained. Depending on the obtained thickness, different interlocks were formed. The interlock size $t_{n}$ and $t_{s}$ are presented in Tab. 4, and the interlock views of the round clinching joints are shown in Fig. 13a.

Table 4 Interlock dimension of a RCL joint

\begin{tabular}{|l|c|c|c|c|c|}
\hline \multicolumn{2}{|l|}{ Joint embossment thickness $X(\mathrm{~mm})$} & 0,7 & 0,6 & 0,5 & 0,4 \\
\hline \multirow{2}{*}{ Interlock parameter $(\mathrm{mm})$} & $t_{n}$ & 0,42 & 0,41 & 0,50 & 0,45 \\
\cline { 2 - 6 } & $t_{s}$ & 0,15 & 0,17 & 0,19 & 0,17 \\
\hline
\end{tabular}

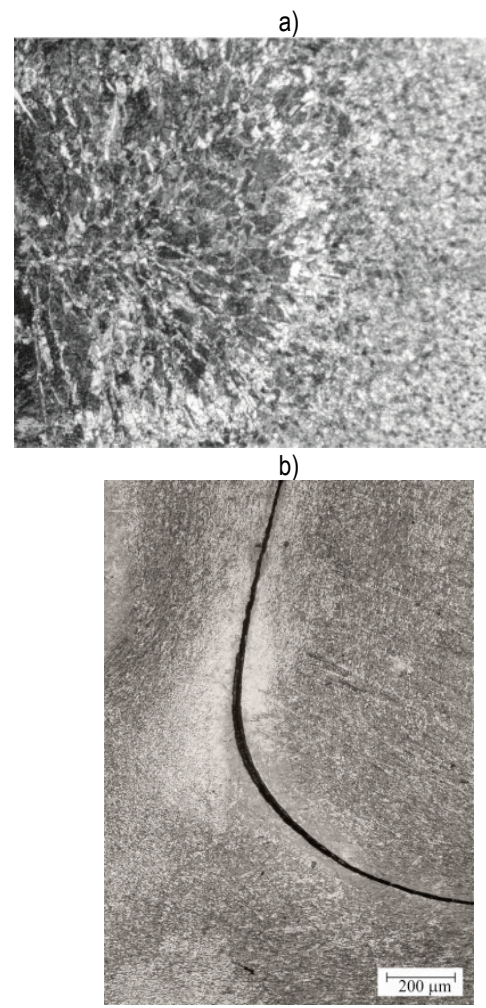

Figure 14 Microstrutures of: a) resistance spot welded joints, b) round clinching joint

In the case of a spot welded joint, characteristic areas of thermo-mechanical change of structure were obtained (Fig. 14a). For blind rivet joints a pre-drilling process is required. On the other hand the pressed joints do not require the drilling process and they are formed in a cold process. However, in result of strong local deformation, changes of material sheet structures were observed. Material strengthening increases the joint strength. Too high deformation intensity can lead to joint weakening [26, $30 \div 32$ ]. Examples of RCL joint structure changes are presented in Fig. 14b (close to the joint interlock). Structure changes in SW joints (grain growth) were related to heat influence (Fig. 14, and Fig. 8). For a RCL joint the material structure and grain arrangement depend on the material flow intensity (Fig. 14b). To compare shearing force transfer capability average values of $F_{s} \max$ for all types of used joints are presented in Fig. 15.

In the shearing test of pressed joints a different destruction mechanism was observed. It is widely known that maximum load capacity depends on the cross-section area of joint. Determination of maximum strength of rivet and spot welded joints is relatively easy and the results of the analytical calculations are similar to the results from the experimental research.

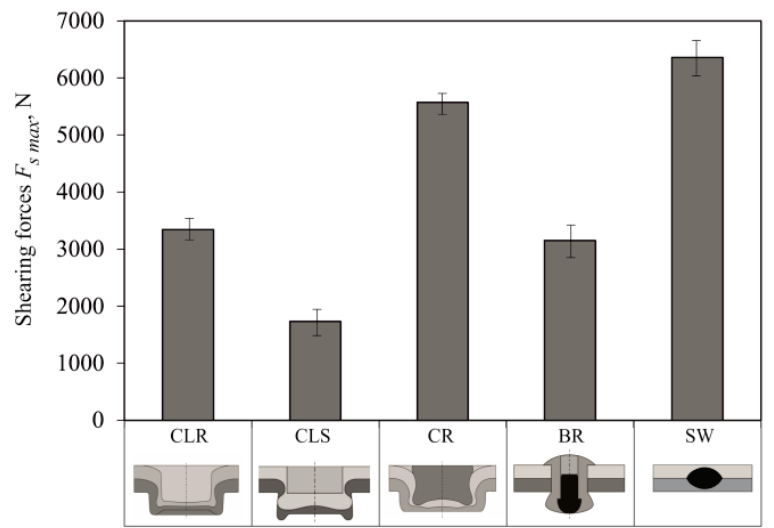

Figure 15 Average joints strength from shearing test

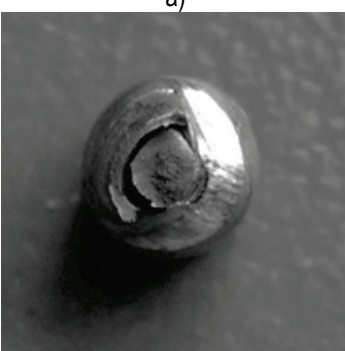

c)

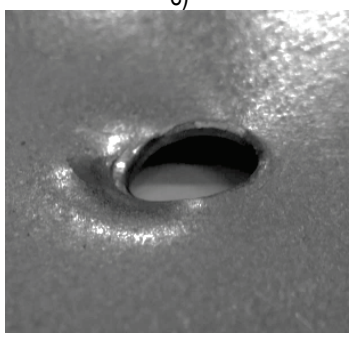

Figure 16 Blind rivet lap joint after shearing test: a) fracture rivet surface, b) deformed part of the rivet head, $c$ ) sheet form the secondary rivet head, d) sheet form the rivet head

During the shearing test in the first phase the blind rivet deforms as a result of relative movement of the sheet and a "rivet head" (fractured pivot). The clearance between fastener and hole was cleared and slight movement of the fracture pivot was obtained. Further load transfer without the tubular part of rivet deformation was impossible. When the rivet head was blocked the distortion was concentrated in the tubular part of the rivet. Under the load and slight rotation of the rivet its tubular part was cut (Fig. 16a, b). The rivet flange was bent (Fig. 16b) in result of the lack of symmetry of the rivet supporting area (joint is not symmetrical on either side of sheets). The sheets were deformed in the vicinity of the hole area (Fig. 16c, d).

Due to intense plastic deformation and associated material strengthening, it is difficult to calculate the maximum strength of pressed joints. There are studies in which researchers use correction factors [32 $\div 34]$. Hence, for pressed joints the most appropriate method of strength determination is the shearing test.

Under force load the square clinching joint with material incision (SCL) was destroyed by cut of upper sheet interlock (Fig. 17a). In the bottom sheet due to the greater load capacity of material incision the embossment was not cut (Fig. 17b). Surface pressure was higher than the shear strength of the upper sheet. This destruction mechanism for that joint was described in [35]. 


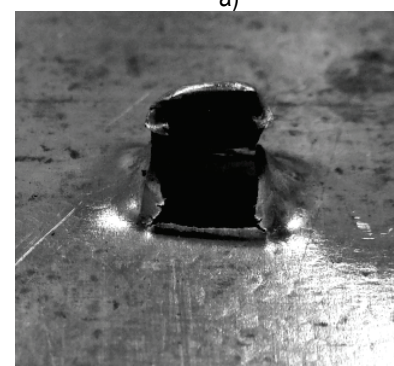

Figure 17 Embossment view of square clinching joint after shearing test: a) top sheet, b) bottom sheet

Round clinching joints (RCL) under force load behaved in a similar way to the other pressed joints. However, it should be noted that thickness of the embossment $(X)$ affects the destruction mechanism [17]. In Fig. 18 the upper sheets of joints after the shearing test were presented for two different values of the $X$ parameter. Reduction of the embossment thickens requires increase of the forming force (Fig. 12). The cylindrical part of the interlock is thinning (upper sheet from the punch side). Material strengthening and cylindrical part of interlock thinning have influence on the $\mathrm{CL}$ joint destruction mechanism.
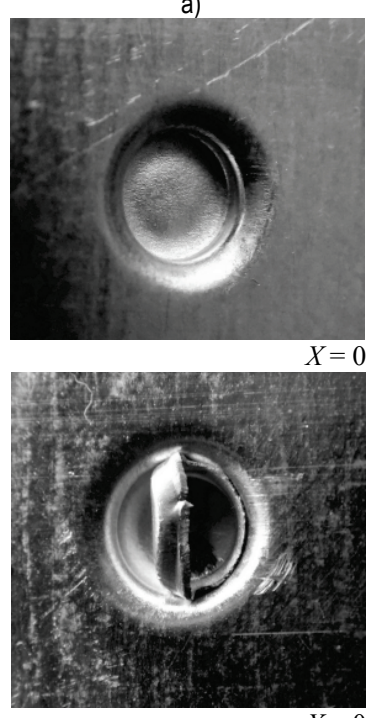

$X=0,4 \mathrm{~mm}$

Figure 18 Embossment view (CL joint) after shearing test for two values of $X$ parameter: a) bottom sheet, b) top sheet a)

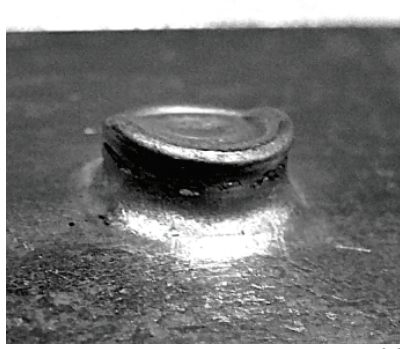

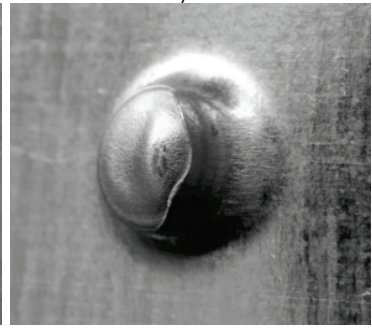

$7 \mathrm{~mm}$

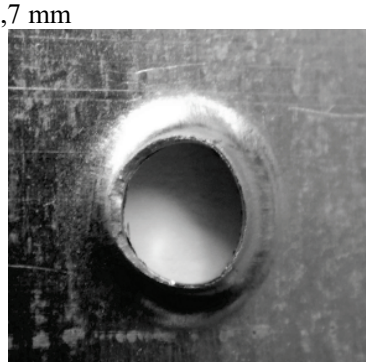

ing test for two values of $X$ b)

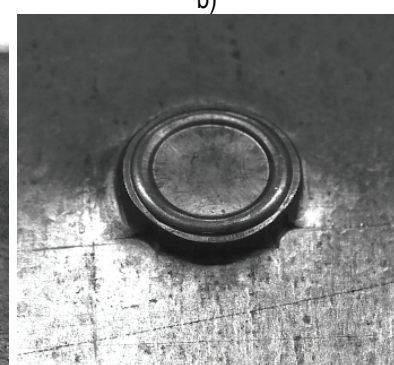

Figure 19 Round embossment view of ClinchRivet joint (CR) after shearing test a) top sheet, b) bottom sheet

The pressing joining method was a cold process. Due to oxidation of the galvanic coating, hot joining process was not performed. One of the methods to reduce material strengthening is the joining process at elevated temperature. The use of heating also allows to join hardly deformable materials [36].

The ClinchRivet joint (CR) was one of the pressed joints that was analyzed in this paper. An additional rivet, which is used for stiffening joints and increasing the joint load capacity, also affects the joint destruction mechanism (Fig. 19). The use of special rivets requires changing die construction. Movable segments allow for radial of river material. The pressed rivet presses the sheet material to flow in a perpendicular direction to the punch movement. Thus, the interlock is formed [6].

In the case of CR joints the cross section of the rivet is large enough so the rivet is not cut. Failure of the joint is caused by rivet upsetting with simultaneous pulling out form the bottom sheet. During separation of the sheets the coherence loss of upper sheet was observed (Fig. 19a). In the bottom sheet the lossiness of material coherence was not observed (Fig. 19b). The use of a rivet in a pressed joint resulted in significantly higher shearing force (Fig. 15).

Another method to increase the CL joint strength without using an additional rivet is the method of controlled re-pressing [37]. However, this technology requires two phases of joint forming with two different tool types.

The clinching joints are classified as environmentally friendly joining technology. They are the least harmful to the environment [38]. The pressing force is higher than in the welding process, however the energy consumption of the welding process depends on the value of the welding current. In addition, during the welding process harmful gas vapors and dangerous hot spalls are emitted. Disposal of gases raises the cost of the joining process.

Taking into account the cost of joints the round clinching technology is the cheapest among other technologies. In the case of modification of the clinching technology by using an additional rivet (CR technology) the joint cost is raised by the fastener. In addition the forming force in the $\mathrm{CR}$ joining process is higher than in the CL technology (the process energy consumption increases). The pressing tools deform the sheets and rivet during the joining process.

The smallest tool wear, and associated tools amortization cost, is obtained for round tools. One of the leading tools manufactures, ToxPressotechnik, declares durability of their tools at the level of several hundred thousand cycles.

Pressing technology is easy to automate. The cost of the apparatus is more expensive than that of the welding technology. Joining with an additional rivet (CR) requires an additional rivet feeder. The smallest amount of space needed by an industrial robot to operate is required by welding technology, then by clinching technology, and finally by joining with additional rivet.

For a round clinching joint an important aspect is the need of tool positioning relative to each other (parallelism of side surfaces). In the case of round clinching joints the tools need to be arranged concentrically.

\section{CONCLUSION}

- Increase of the welding current to a certain value gives measurable benefits in terms of the increase of SW 
joint strength. Increase over that value does not ensure high increase of the joint strength.

- Pressed joints are alternative to resistance spot welding. However, the forming force strongly influences the joint strength.

- For round clinching joints (RCL) in order to achieve the assumed joint strength with relatively low forming force the joining process can be controlled by minimum embossment thickens ( $X$ parameter). Reduction of $X$ parameter results in the decrease of the total displacement for joint separation.

- The use of an additional rivet (CR) increases the joint strength with respect to the RCL joint. The CR joint has the same strength as the SW joint.

\section{Acknowledgements}

This work was conducted under the project KEGA 065TUKE-4/2017 - Innovation of educational process in education of $\mathrm{CAD} / \mathrm{CAM} / \mathrm{CAE}$ systems using computational cluster GRID.

\section{REFERENCES}

[1] EN 10326:2004. Continuously hot-dip coated strip and sheet of structural steels.

[2] EN1993-1-3:2005. Eurocode 3: Design of steel structures. Part 1-3: General rules - Supplementary rules for coldformed members and sheeting.

[3] EN1993-1-8:2005. Eurocode 3: Design of steel structures. Part 1-8: Design of joints.

[4] Kaitila, O. (1998). Study on the Behaviour of a New LightWeight Steel Roof Truss. Journal of Structural Mechanics, 31(3-4), 4-15.

[5] Mäkeläinen, P. \& Kesti, J. (1999). Advanced method for lightweight steel joining. Journal of Constructional Steel Research, 49(2), 107-116. https://doi.org/10.1016/S0143-974X(98)00210-7

[6] Mucha, J. \& Witkowski, W. (2013). The experimental analysis of the double joint type change effect on the joint destruction process in uniaxial shearing test. Thin-Walled Structures, 66, 39-49. https://doi.org/10.1016/j.tws.2013.01.018

[7] Ghosh, A., Chattopadhyaya, S., \& Hloch, S. (2012). Prediction of weld bead parameters, transient temperature distribution \& HAZ width of submerged arc welded structural steel plates. Tehnički vjesnik, 19(3), 617-620. https://doi.org/10.4028/www.scientific.net/DDF.326-328.405

[8] Ghosh, A., Hloch, S., \& Chattopadhyaya, S. (2014). Critical analysis of moving heat source shape for arc welding process of high deposition rate. Tehnički vjesnik, 21(1), 95-98.

[9] Michalec, I., Maronek, M., Barta, J. et al. (2012). Weld joints fatigue properties of thin carbon steel sheet treated by nitrooxidation. Tehnički vjesnik, 19(1), 65-69.

[10] Chen, C., Zhao, S. D., Han, X. L., Cui, M. C., \& Fan, S. Q. (2016). Optimization of a reshaping rivet to reduce the protrusion height and increase the strength of clinched joints. Journal of Materials Processing Technology, 234, 1-9. https://doi.org/10.1016/j.jmatprotec.2016.03.006

[11] Chen, C., Zhao, S. D., Cui, M. C., Han, X. L., \& Fan, S. Q. (2016). Mechanical properties of the two-steps clinched joint with a clinch-rivet. Journal of Materials Processing Technology, 237, 361-370. https://doi.org/10.1016/j.jmatprotec.2016.06.024

[12] Chen, C., Zhao, S. D., Han, X. L., Cui, M. C., \& Fan, S. Q. (2016). Investigation of mechanical behavior of the reshaped joints realized with different reshaping forces. Thin-Walled Structures, 107, 266-273. https://doi.org/10.1016/j.tws.2016.06.020

[13] Chen, C., Zhao, S. D., Cui, M. C., Han, X. L., \& Fan S. Q. (2016). An experimental study on the compressing process for joining Al6061 sheets. Thin-Walled Structures, 108, 5663. https://doi.org/10.1016/j.tws.2016.08.007

[14] Chen, C., Zhao, S. D., Cui, M. C., Han, X. L., \& Ben, N. Y. (2017). Numerical and experimental investigations of the reshaped joints with and without a rivet. The International Journal of Advanced Manufacturing Technology, 88, 5, 2039-2051. https://doi.org/10.1007/s00170-016-8889-5

[15] Chen, C., Zhao, S. D., Han, X. L., Cui, M. C., \& Fan S. Q. (2017). Investigation of the height-reducing method for clinched joint with AL5052 and AL6061. The International Journal of Advanced Manufacturing Technology, 89(5), 2269-2276. https://doi.org/10.1007/s00170-016-9266-0

[16] Chen, C., Han, X., Zhao, S., Xu, F., Zhao, X., Ishida, T. (2017). Comparative study on two compressing methods of clinched joints with dissimilar aluminum alloy sheets. The International Journal of Advanced Manufacturing Technology, 93(5-8), 1929-1937. https://doi.org/10.1007/s00170-017-0650-1

[17] Mucha, J. (2011). The analysis of lock forming mechanism in the clinching joint. Materials \& Design, 32(10), 49434954. https://doi.org/10.1016/j.matdes.2011.05.045

[18] Lambiase, F. \& Di Ilio, A. (2016). Damage analysis in mechanical clinching: Experimental and numerical study. Journal of Materials Processing Technology, 230, 109-120. https://doi.org/10.1016/j.jmatprotec.2015.11.013

[19] Lambiase, F. \& Di Ilio, A. (2013). Optimization of the Clinching Tools by Means of Integrated FE Modeling and Artificial Intelligence Techniques. Procedia CIRP, 12, 163168. https://doi.org/10.1016/j.procir.2013.09.029

[20] Lambiase, F. \& Ko, D-Ch. (2017). Two-steps clinching of aluminum and Carbon Fiber Reinforced Polymer sheets. Composite Structures, 164, 180-188. https://doi.org/10.1016/j.compstruct.2016.12.072

[21] Lambiase, F., Durante, M., \& Di Ilio, A. (2016). Fast joining of aluminum sheets with Glass Fiber Reinforced Polymer (GFRP) by mechanical clinching. Journal of Materials Processing Technology, 236, 241-251. https://doi.org/10.1016/j.jmatprotec.2016.04.030

[22] Lambiase, F. \& Ko, D-Ch. (2016). Feasibility of mechanical clinching for joining aluminum AA6082-T6 and Carbon Fiber Reinforced Polymer sheets. Materials \& Design, 107, 341-352. https://doi.org/10.1016/..matdes.2016.06.061

[23] Lambiase, F., Paoletti, A., \& Di Ilio. (2017)Advances in Mechanical Clinching: Employment of a Rotating Tool. Procedia Engineering, 183, 200-205. https://doi.org/10.1016/j.proeng.2017.04.021

[24] Mucha, J. \& Witkowski, W. (2015). Mechanical Behavior and Failure of Riveting Joints in Tensile and Shear Tests. Strength of Materials, 47(5), 755-769. https://doi.org/10.1007/s11223-015-9712-5

[25] Viňáš, J., Kaščák, L., \& Greš, M. (2016). Optimization of resistance spot welding parameters for microalloyed steel sheets. Open Engineering, 6, 504-510. https://doi.org/10.1515/eng-2016-0069

[26] Mucha, J., Kaščák, L., \& Spišák, E. (2011). Joining the carbody sheets using clinching process with various thickness and mechanical property arrangements. Archives of Civil and Mechanical Engineering, 11(1), 135-148. https://doi.org/10.1016/S1644-9665(12)60179-4

[27] Kaščák, L., Spišák, E., Spišáková, E., \& Gajdoš, I. (2015). Clinching - An Innovative Trend in Joining of Combined Materials in Car Body Production. Materials Science Forum, 818, 217-220. https://doi.org/10.4028/www.scientific.net/MSF.818.217 
[28] Mucha, J. (2016). Analysis of stress distribution in the die during the self-piercing riveting process. Advances in Manufacturing Science and Technology, 40(4), 43-54.

[29] Kaščák, L., Spišák, E., Kubik, R., \& Mucha J. (2016). FEM Analysis of Clinching Tool Load in a Joint of Dual-Phase Steels. Strength of Materials, 48(4), 533-539. https://doi.org/10.1007/s11223-016-9795-7

[30] Mucha, J. (2010). The characteristics of H320LA steel sheet clinching joints. Advances in Manufacturing Science and Technology, 34(4), 47-61.

[31] Mucha, J. \& Witkowski, W. (2014). The clinching joints strength analysis in the aspects of changes in the forming technology and load conditions. Thin-Walled Structures, 82, 55-66. https://doi.org/10.1016/j.tws.2014.04.001

[32] He, X., Yu, T., Gao, A., \& Zhang, Y. (2016). Investigations of Join-Ability and Energy Absorption of Clinched Joints in Titanium and Aluminum-Lithium Sheet Materials. Materials Transactions, 57(10), 1849-1852. https://doi.org/10.2320/matertrans.M2016223

[33] He, X. C., Gao, A. F., Yang, H. Y., \& Xing, B. Y. (2016). Mechanical Behavior of Clinched Sheet Material Joints and Strength Design Procedure. Acta Physica Polonica A, 129(4), 698-700. https://doi.org/10.12693/APhysPolA.129.698

[34] He, X., Liu, F., Xing, B., Yang, H., Wang, Y., Gu, F., \& Ball, A. (2014). Numerical and experimental investigations of extensible die clinching. The International Journal of Advanced Manufacturing Technology, 74(9-12), 1229-1236. https://doi.org/10.1007/s00170-014-6078-y

[35] Mucha, J. (2011). The analysis of rectangular clinching joint in the shearing test. Eksploatacja $i$ Niezawodnosc Maintenance and Reliability 3(51), 45-50.

[36] Lambiase, F. (2015). Clinch joining of heat-treatable aluminum AA6082-T6 alloy under warm conditions. Journal of Materials Processing Technology, 225, 421-432. https://doi.org/10.1016/j.jmatprotec.2015.06.022

[37] Chen, C., Zhao, S., Han, X., Cui, M., Zhao, X., \& Ishida, T. (2017). Experimental investigation of the mechanical reshaping process for joining aluminum alloy sheets with different thicknesses. Journal of Manufacturing Processes, 26, 105-112. https://doi.org/10.1016/j.jmapro.2017.01.015

[38] Varis, J. (2006). Economics of clinched joint compared to riveted joint and example of applying calculations to a volume product. Journal of Materials Processing Technology, 172, 130-138.

https://doi.org/10.1016/j.jmatprotec.2005.09.009

\section{Contact information:}

\section{L'uboš KAŠČÁK, DSc. PhD, Eng.}

Technical University of Košice

Mäsiarska 74, 04001 Košice, Slovakia

E-mail: lubos.kascak@tuke.sk

Jacek MUCHA, DSc. PhD, Eng.

Rzeszow University of Technology,

Al. Powstańców Warszawy 12, 35-959 Rzeszów, Poland

E-mail:j_mucha@prz.edu.pl

Waldemar WITKOWSKI, MSc, Eng.

Rzeszow University of Technology,

Al. Powstańców Warszawy 12, 35-959 Rzeszów, Poland

E-mail: wwitkowski@prz.edu.pl 